RADOSŁAW REPETOWSKI

Uniwersytet Ekonomiczny, Kraków

\title{
Zmiany w marketingowej orientacji przedsiębiorstw przemyslowych w dobie postępującej globalizacji
}

Współczesne przedsiębiorstwa stoją przed wielkim wyzwaniem, jakim niewątpliwie jest konkurowanie na coraz to bardziej jednolitym rynku międzynarodowym, kształtującym się pod wpływem procesów globalizacji. Dlatego też marketing zyskał rangę jednego z najbardziej istotnych składników filozofii świata biznesu. Jest on jedną z podstawowych orientacji menedżerskich oraz zbiorem rynkowych narzędzi zarządzania. Termin „marketing” pojawił się w Stanach Zjednoczonych, zanim tamtejsza gospodarka osiągnęła poziom rozwoju, którego efektem było upowszechnienie się rynkowej orientacji przedsiębiorstw. Skuteczność działalności przedsiębiorstwa na rynku zależy w głównej mierze od doboru odpowiednich narzędzi marketingowych, przy pomocy których przedsiębiorstwo działa na tym rynku. Tu nasuwa się pytanie: jak skutecznie konkurować w dobie postępującej globalizacji oraz jak dużą rolę odegrała globalizacja w kształtowaniu się marketingu.

\section{UWARUNKOWANIA ROZWOJU TEORII MARKETINGU \\ W PROCESIE GLOBALIZACJI}

Proces globalizacji został zapoczątkowany przez wielkie odkrycia geograficzne w XV i XVI w., pod wpływem, których powstała merkantylistyczna myśl ekonomiczna, tworzona przez przedsiębiorców handlowych. Twierdzili oni, że handel zagraniczny ma korzystny wpływ na wzrost potęgi gospodarczej państwa i dobrobytu obywateli. Merkantylizm głosił, że głównym miernikiem bogactwa państwa i jego siły gospodarczej jest ilość nagromadzonego pieniądza kruszcowego, a jedynym środkiem pozwalającym na zdobycie dużej ilości złota i srebra jest handel zagraniczny, głównie w postaci eksportu. Dla merkantylistów import był głównym powodem odpływu pieniądza z kraju i był on uzasadniony tylko w przypadku, gdy służył do zakupu surowców niezbędnych do produkcji, która może być eksportowana za granicę (Nasiłkowski 1998). Dlatego też kooperacja między oddalonymi od siebie ośrodkami aktywności ekonomicznej była jednym z priorytetów ówczesnych przedsiębiorców.

W drugiej połowie XVIII w. w Anglii powstał pierwszy zwarty system teoretyczny zwany ekonomią klasyczna. Do głównych przedstawicieli tego nurtu można zaliczyć Adama Smitha oraz Davida Ricardo, których teorie stanowią podbudowę dla koncepcji liberalizmu gospodarczego. Istotą tej doktryny ekonomicznej jest brak ingerencji państwa oraz innych 
instytucji politycznych w stosunki gospodarcze. Podstawą doktryny liberalizmu gospodarczego jest zasada korzyści materialnej (homo oeconomicus) (Księżyk, Duda 1997). Liberalizm gospodarczy w sferze ekonomicznej przejawiał się w postaci kapitalizmu wolnokonkurencyjnego. Koncepcja ta zakładała, że głównym strategicznym czynnikiem rozwoju gospodarczego państwa jest gromadzenie pieniądza. Zwolennicy tej teorii twierdzili, że dostatecznie duża konkurencja oraz wysoka stopa zysku jest podstawą szybkiego rozwoju gospodarczego. W warunkach wolnej konkurencji przedsiębiorcy lokują swój kapitał w tych gałęziach przemysłu, które zapewniają największą możliwą stopę zysku, co prowadzi do szybkiego wzrostu gospodarczego państwa. Na tych przesłankach opiera się liberalna koncepcja państwa nieingerującego w sferę gospodarki. W takim państwie dobrobyt społeczeństwa zależy od zapewnienia wszystkim uczestnikom rynku możliwie największej swobody w działaniu prowadzącej do osiągnięcia najwyższej efektywności ekonomicznej. W teorii tej rola państwa ogranicza się do prawnej ochrony własności prywatnej, stwarzając jednocześnie warunki sprzyjające rozwojowi działalności gospodarczej opartej na zasadach wolnej konkurencji. Uważano, że narody mogą ze sobą skutecznie handlować, a wszelkie wahania w zakresie popytu i podaży samoczynnie się uregulują, bez ingerencji rządów państw ze sobą współpracujących.

Przyspieszenie rozwoju gospodarki, które miało miejsce w drugiej połowie XIX w. miało znaczący wpływ na rynkową orientację przedsiębiorstw. Odkrycia geograficzne oraz innowacje w dziedzinie technologii i organizacji produkcji umożliwiły zwiększenie efektywności działalności gospodarczej poprzez zastosowanie produkcji masowej, obniżenie kosztów oraz poszerzenie rynków zbytu. Ówczesny rynek był ubogi pod względem zróżnicowania asortymentowego. Jedynie podstawowe potrzeby ludności były zaspokajane masowo. Dominowała sytuacja określana mianem rynku sprzedawcy. Działalność przedsiębiorstwa skupiała się głównie na technicznych aspektach produkcji dóbr. Dla ówczesnych przedsiębiorców najważniejsze było utrzymanie ciągłości produkcji, natomiast zbyt towarów i jakość wyrobów były problemem drugorzędnym. Dlatego też dominującą rolę odgrywały innowacje techniczne, a w szczególności innowacje procesowe. Wzrastający stopień nasycenia rynku, niska jakość oferowanych dóbr i brak stosowania innowacji produktowych doprowadziły do pojawienia się problemów ze zbytem produktów. Przyczyną załamania gospodarki był gwałtowny spadek cen, spowodowany szybkim wzrostem konkurencji międzynarodowej i znacznym nasyceniem rynku.

Szczególne znaczenie w osłabieniu tendencji globalizacyjnych miał największy kryzys gospodarczy XIX wieku. Redukcja kosztów transportu otworzyła rynki zachodniej Europy dla taniego zboża z Ameryki i Ukrainy. Masowy import produktów rolnych doprowadził do gwałtownego spadku cen, a w konsekwencji do obniżenia dochodów rolników i załamania się popytu na wyroby przemysłowe. Trwająca na zachodnioeuropejskich rynkach depresja wpłynęła zarówno na politykę ekonomiczną krajów, jak i na zachowania przedsiębiorców. Zaczęto dostrzegać fakt, że gospodarka nie jest zdolna samoczynnie utrzymać się w stanie równowagi. Zachodnioeuropejscy chłopi i przemysłowcy jednogłośnie opowiadali się za wprowadzeniem do polityki gospodarczej państwa instrumentów umożliwiających permanentną ochronę rynku wewnętrznego. Wiele rządów wprowadziło cła zaporowe na produkty rolne i przemysłowe. Wprowadzenie tego typu ceł skutecznie zahamowało rozwój handlu międzynarodowego i jednocześnie zmusiło przedsiębiorców do koncentracji działań na rynkach krajowych. Załamanie gospodarki i wzrost konkurencji na rynkach krajowych było powodem zamknięcia wielu małych i średnich przedsiębiorstw. Na skutek tego nastapił okres 
masowego przejmowania małych i słabych podmiotów gospodarczych przez silne, dobrze prosperujące przedsiębiorstwa przemysłowe. Duże przedsiębiorstwa coraz częściej zawierały między sobą porozumienia mające na celu ograniczenie skutków niszczącej konkurencji. Celem tych porozumień było uzgodnienie poziomu cen, co pozwalało na osiągnięcie pozycji monopolistycznej na rynku narodowym.

W Stanach Zjednoczonych powstał trust Standard Oil składający się z wielu mniejszych, stopniowo przejmowanych przez Standard Oil przedsiębiorstw. W Europie powstały koncerny chemiczne oraz koncerny górniczo-hutnicze. Skala produkcji wielkich koncernów była powodem szybkiego nasycenia rynków krajowych, dlatego też na początku XX w. koncerny te rozszerzyły swoje rynki zbytu i zaczęły konkurować między sobą na rynku międzynarodowym. Chcąc ograniczyć konkurencję na globalnym rynku, zawierano umowy, na mocy których przedsiębiorstwa z różnych krajów ściśle ze sobą współpracowały, a w większości przypadków łączyły się tworząc pierwsze ponadnarodowe korporacje. Przykładem takiej organizacji może być koncern Royal Dutch Shell Group, który powstał w 1907 r. z połączenia przedsiębiorstwa holenderskiego Royal Dutch Petroleum Company i angielskiej firmy Shell Transport \& Trading Company. Porozumienie to było oparte na zasadach holdingu, gdzie 60\% zysku przypadało Royal Dutch Petroleum Company, a 40\% otrzymywało Shell Transport \& Trading Company (www.shell.com).

Duże znaczenie dla rozwoju globalizacji miała zarówno transkontynentalna, jak i wewnątrzkontynentalna migracja ludności, z którą wiązał się również przepływ kapitału, myśli technicznej, obyczajów oraz myśli ekonomicznej. Skutkiem masowego przemieszczania się ludności był napływ siły roboczej do krajów uprzemysłowionych. Pozwalało to na obniżenie kosztów produkcji i na zwiększenie jej wielkości. W literaturze przedmiotu szczególnie podkreślana jest rola Wielkiej Brytanii, jako kraju, który odegrał dominującą rolę w rozwoju przemysłowym, bankowym, a także kolonialnym. Wielka Brytania skutecznie handlowała ze swoimi koloniami, gdzie pozyskiwała surowce oraz wyroby gotowe. Czynnikami hamującymi rozwój handlu zagranicznego były niewątpliwie wojny światowe. W okresie pierwszej wojny światowej handel zagraniczny został ograniczony. Główną tego przyczyną była izolacja niektórych krajów, wprowadzanie regulacji dotyczących eksportu oraz importu, a przede wszystkim wrogości w stosunkach międzynarodowych. Rozwój globalizacji został zahamowany również w okresie międzywojennym. Powodem tego były ekonomiczne skutki wojny. W kolejnych krajach znoszono system kartkowy i uwalniano ceny, co skutkowało deprecjacją pieniądza i szybkim wzrostem cen. Jednocześnie liberalizowano zewnętrzną wymienialność walut, skutkiem czego ich wzajemne, zablokowane podczas wojny kursy zaczęły się zmieniać, odzwierciedlając tempo inflacji w poszczególnych krajach.

W związku z ogólnoświatową sytuacją ekonomiczną w 1920 r. w Brukseli zorganizowano międzynarodową konferencję, której wynikiem była decyzja o powrocie waluty złotej i zastosowaniu mechanizmu deflacji. Niestety, próba ta nie powiodła się, głównie z powodu braku odpowiednich ilości kruszcu. Przed pierwszą wojną światową produkcja złota wynosiła 700 ton rocznie, natomiast w 1922 r. wydobywano już tylko 480 ton kruszcu (www.gazetabankowa.pl). W Stanach Zjednoczonych doszło do kryzysu spowodowanego zamknięciem się Europy na import amerykański. Kraje europejskie były zadłużone i nie chciały powiększać zadłużenia. Natomiast w państwach pokonanych inflacja zamknęła rynki na import. Społeczne skutki załamania pogłębiła demobilizacja armii. Powracający z frontu żołnierze nie mogli znaleźć zatrudnienia. Skutkiem kryzysu w Stanach Zjednoczonych było wprowadzenie w 1921 r., ograniczeń imigracyjnych wobec Europejczyków. Wielka Brytania, 
w 1925 r. przywróciła wymienialność funta i stała się krajem o wysokich kosztach produkcji, co z punktu widzenia gospodarki międzynarodowej czyniło ją mało konkurencyjnym krajem (www. Gazetabankowa.pl). W ramach interwencjonizmu państwowego powszechnie odchodzono od systemu waluty złotej i wprowadzano różnorodne bariery utrudniające import towarów (Szpak 2003). W okresie międzywojennym mimo występujących problemów gospodarczych i zahamowania handlu międzynarodowego można jednak zauważyć pewne przesłanki przemawiające za postępem globalizacji. Dowodem tego może być rosnąca koncentracja produkcji w nowoczesnych gałęziach przemysłu, a także rozwój istniejących i tworzenie się nowych korporacji ponadnarodowych. Upowszechnienie silników spalinowych spowodowało wzrost popytu na paliwo, a to dało początek dynamicznego rozwoju korporacji petrochemicznych. Royal Dutch Shell Group zdecydował się na zakup terenu na brzegu Tamizy w celu budowy siedziby nowo powstałej firmy ShellMex. Przedsiębiorstwo to, będące częścią koncernu, zajmowało się marketingiem produktów Royal Dutch Shell (www.shell. com). Koncerny mające charakter monopolistyczny podjęły intensywne działania na rzecz rozszerzenia swojej działalności zagranicznej. Koncern General Motors kupił niemieckie przedsiębiorstwo motoryzacyjne Opel.

Rozwój transportu morskiego również cechowała duża dynamika. Stosowano wówczas silniki parowe oraz spalinowe, co pozwoliło na budowę większych jednostek specjalistycznych, a jednocześnie przyczyniało się do rozwoju hutnictwa oraz przemysłu petrochemicznego. Porty morskie przystosowano do przyjmowania większej liczby statków. Powstanie pierwszych regularnych połączeń transatlantyckich również było czynnikiem napędzającym proces globalizacji. Dzięki tym połączeniom było możliwe skrócenie czasu podróży. Szybsze i coraz łatwiejsze przemieszczanie się ludności pozwoliło na coraz większe przenikanie się kultur różnych narodów, a w związku z tym przyspieszenie transferu technologii. W roku 1919 powstało KLM Royal Dutch Airlines for the Netherlands and Colonies. Było to pierwsze przedsiębiorstwo zapewniające regularny cywilny transport lotniczy. W późniejszym okresie przekształciło się w ponadnarodową korporację, w której skład wchodzą linie lotnicze KLM Cityhopper, Transavia, Martinair Holland oraz Kenya Airways (www. klm.com). W tym samym roku powstało również nowe przedsiębiorstwo grupy Royal Dutch Shell o nazwie Shell Aviation. Jego głównym celem było zaopatrywanie w paliwo i olej prężnie rozwijającego się transportu lotniczego (www.shell.com).

Przed wybuchem drugiej wojny światowej przywrócono funkcjonowanie waluty złotej. Odnotowano wówczas wzrost wartości eksportu. Niestety, kryzys w latach trzydziestych i druga wojna światowa były przyczyną prawie całkowitego zaniechania wymiany międzynarodowej.

W Polsce kryzys przemysłowy objawił się głównie w postaci spadku produkcji. Produkcja ropy naftowej w 1928 r. wynosiła 743 tys. ton, natomiast w 1932 r. spadła do 557 tys. ton (www.stud.umk.pl). Wielkość produkcji w poszczególnych latach przedstawiono w tab. 1.

Postępujący spadek produkcji stał się przyczyną likwidacji wielu przedsiębiorstw. Przedsiębiorcy chcąc przetrwać, zmuszeni byli zawierać porozumienia, które ograniczały produkcję i utrzymywały określony poziom cen. Największy spadek produkcji można zauważyć w górnictwie i przemyśle ciężkim. Było to rezultatem zahamowania wszelkich inwestycji. Nowe inwestycje zaczęto realizować dopiero po przejściu dna kryzysu, co spowodowało powolne ożywianie się koniunktury w przemyśle (www.stud.umk.pl). 
Tab. 1. Wielkość produkcji surowców i wyrobów w latach kryzysu (w tys. ton)

\begin{tabular}{|l|r|r|r|}
\hline \multicolumn{1}{|c|}{ Surowce/Produkty } & 1928 & 1932 & 1934 \\
\hline Węgiel kamienny & 40616 & 28835 & 29233 \\
\hline Ropa naftowa & 743 & 557 & 529 \\
\hline Ruda żelaza & 699 & 77 & 247 \\
\hline Stal & 1438 & 564 & 856 \\
\hline Cynk & 16 & 85 & 93 \\
\hline Wyroby walcowane & 1048 & 404 & 619 \\
\hline
\end{tabular}

Źródło: opracowanie własne na podstawie www.stud.umk.pl

W Europie Zachodniej kryzys spowodował znaczne ograniczenia w handlu międzynarodowym. Przedsiębiorcy byli zmuszeni do koncentracji swoich działań na rynkach krajowych, które cechowały się dużym stopniem nasycenia. Zaczęto zauważać, że duże znaczenie w osiągnięciu zamierzonego poziomu zysku ma sposób dotarcia do klienta. Zmiana zewnętrznych warunków funkcjonowania przedsiębiorstw i opanowanie zagadnień związanych $\mathrm{z}$ technologią i organizacją masowej produkcji spowodowały zmianę $\mathrm{w}$ hierarchii problemów zarządzania. Większość przedsiębiorstw przeszła z fazy orientacji produkcyjnej w fazę orientacji sprzedażowej, w której dużą wage przywiązuje się do racjonalizacji i intensyfikacji zbytu. W przedsiębiorstwach produkcyjnych zaczęto wyodrębniać działy, których zadaniem była sprzedaż wytwarzanych przez nie produktów. Pojawiły się na rynku pierwsze przedsiębiorstwa handlowe, pełniące rolę pośrednika między producentem a konsumentem finalnym. Rozwinęły się również pierwsze systemy masowej dystrybucji wyrobów. W 1920 r. w Stanach Zjednoczonych została uruchomiona pierwsza hurtownia Cash and Carry. Pierwszy supermarket otwarto w Nowym Jorku w 1930 r., a siedem lat później pierwszy sklep dyskontowy (Altkorn 1997).

Po drugiej wojnie światowej nastąpiło załamanie w stosunkach między Wschodem a Zachodem. Nastał czas zimnej wojny. Pogłębił się podział polityczny i gospodarczy świata. W krajach zachodniej Europy i Stanach Zjednoczonych rozwijał się kapitalizm oparty na wolnym handlu, konkurencji i obrocie kapitału. Natomiast w krajach komunistycznych Europy Wschodniej przyjęto zasadę centralnie sterowanej gospodarki. Rozłam ten wywarł duży wpływ na funkcjonowanie i rozwój teorii marketingu. W krajach wschodnioeuropejskich władze państwa decydowały, co i w jakich ilościach należy produkować. Ograniczono własność prywatną. Wszystkie duże przedsiębiorstwa przemysłowe i handlowe stanowiły własność państwa. Z uwagi na brak konkurencji oraz centralnie planowaną produkcję i zbyt wszelkie działania marketingowe stały się zbędne. Jednakże ustrój komunistyczny i zahamowanie rozwoju marketingu nie wpłynęło na tendencje globalizacyjne w rejonie Europy Wschodniej.

W 1949 r. z inicjatywy Stalina powstała Rada Wzajemnej Pomocy Gospodarczej (RWPG), której głównym zadaniem było wspieranie planowanego rozwoju gospodarki narodowej, przyspieszanie postępu technicznego, podniesienie poziomu industrializacji oraz wzrost wydajności pracy i zwiększenie dobrobytu państw członkowskich. Rada koncentrowała się na intensyfikacji wymiany wewnętrznej, zastępując tym samym istniejące wcześniej kontakty handlowe z Zachodem. RWPG stanowiło niejako odpowiedź Stalina na założoną w 1948 r. Organization for European Economic Co-operation (OEEC), zrzeszającą 16 państw. 
W Stanach Zjednoczonych i Europie Zachodniej narzędzia marketingu, takie jak dystrybucja, reklama czy sprzedaż osobista, były skutecznie stosowane przez przedsiębiorców. Marketing jako przedmiot nauczania pojawił się po raz pierwszy w Stanach Zjednoczonych w drugiej połowie XX w. na kursach dystrybucji, sprzedaży hurtowej i detalicznej. Pojawienie się marketingu jako przedmiotu było uwarunkowane dostrzeżeniem przez specjalistów od marketingu pewnego rodzaju luki intelektualnej powstałej w skutek pominięcia przez ekonomistów zagadnień związanych ze zmianą ceny w łańcuchu dystrybucji (Kotler 2004).

Podpisany w 1947 r. w Genewie Układ Ogólny w Sprawie Taryf Celnych i Handlu (General Agreement on Tariffs and Trade - GATT) był czynnikiem stymulującym rozwój globalizacji. Porozumienie to miało na celu ułatwienie stosunków międzynarodowych dzięki eliminacji dyskryminacji i liberalizacji handlu zagranicznego poprzez kontrolowanie i usuwanie przeszkód stojących na drodze rozwoju współpracy międzynarodowej. Jednym z najważniejszych efektów funkcjonowania GATT było znaczne obniżenie ceł (wikipedia. org, 2). W Europie Zachodniej i Stanach Zjednoczonych w drugiej połowie lat 50. XX w. rynki stały się w pełni rynkami konsumenta. Powojenny boom gospodarczy spowodował szybki wzrost wielkości produkcji i dochodów społeczeństwa. Coraz większa część dochodów gospodarstw domowych była przeznaczana na tzw. fundusz swobodnej decyzji, który stanowił obiekt zainteresowania przedsiębiorstw różnych sektorów gospodarczych. Mimo że produkty oferowane na danym rynku różniły się, zarówno pod względem fizycznym, jak i przeznaczeniem, to faktycznie wchodziły one w relacje konkurencyjne. Nastała potrzeba dostosowania oferty do faktycznych potrzeb nabywców. Powstał problem aktywnego kształtowania struktury potrzeb, tak by odpowiadała ona interesom poszczególnych sektorów i korporacji. Upowszechnienie się i rozwój systemów transportu i łączności oraz rola radia i telewizji w kontaktach społecznych sprawiły, że coraz więcej rynków przekształciło się w rynki ponadnarodowe i globalne.

Przyspieszenie rozwoju globalizacji w drugiej połowie XX w. stwarzało dla przedsiębiorców szanse zdobycia nowych potencjalnych nabywców. Jednakże istniało również zagrożenie pojawienia się konkurencji z innych krajów. Szybki rozwój nauki i techniki powodował nasilenie się tendencji innowacyjnych. Po drugiej wojnie światowej w praktyce zarządzania przedsiębiorstw dominował tzw. liniowy model innowacji. Wczesne modele procesu innowacji kładły nacisk na przyczynową rolę osiagnięć naukowo-technicznych. Tego typu model określany jest jako model innowacji „pchanej” przez naukę. Zakłada on, iż osiagnięcia sfery badań podstawowych prowadzą do rozwoju techniki przemysłowej, która powoduje wpływ nowych produktów i procesów technologicznych na rynek. Tak więc polityka przedsiębiorstwa bazująca na takim modelu kładzie nacisk na czynniki podażowe, ignorując jednocześnie czynniki popytowe. Rola, jaką w procesie innowacyjnym odgrywają odczuwane potrzeby rynkowe, zaczęła być akcentowana dopiero od połowy lat 60 . Stwierdzono bowiem, że $75 \%$ udanych innowacji pojawiło się jako reakcja na rozpoznanie potrzeby rynkowej. Zostało to ujęte jako liniowy model innowacji ,ciagnnionej” przez rynek. W modelu tym innowacje techniczne powstaja jako rezultat dostrzeżonych i przejrzyście wyartykułowanych potrzeb społecznych (Jasiński 1992).

W latach 1950-1973 kraje uprzemysłowione charakteryzowały się wysoką dynamiką rozwoju, której źródłem było wykorzystanie osiągnięć rewolucji naukowo-technicznej. Wyznacznikiem rewolucji stał się rozwój elektroniki, energetyki jądrowej oraz produkcja nowych materiałów syntetycznych. Zmniejszyła się rola indywidualnych badań i samodziel- 
nych wynalazców. Nauka i technika stały się dominującymi siłami napędowymi gospodarki międzynarodowej. W Stanach Zjednoczonych dokonano wielu zmian w sposobie zarządzania przedsiębiorstwem. Wprowadzono funkcjonalne układy zależności między poszczególnymi działami przedsiębiorstw. W strukturze dużych przedsiębiorstw wyodrębniono samodzielne jednostki zajmujące się produkcją, sprzedażą, finansami, badaniami i marketingiem. Dyrektorzy działów tworzyli zarząd przedsiębiorstwa i wspólnie decydowali o jego przyszłości. W krajach zachodniej Europy transfer technologii odbywał się za pośrednictwem ponadnarodowych korporacji przemysłowych, handlowych i transportowych. Konsekwencją tego było skrócenie się przeciętnego cyklu życia produktu.

Wzrost kapitałochłonności prac badawczo-rozwojowych oraz inwestycji związanych z uruchamianiem produkcji i wprowadzaniem nowych produktów na rynek wymagał podejmowania działań na rzecz zmniejszenia ryzyka inwestycji. Stopień ryzyka można zmniejszyć dostosowując produkty do zróżnicowanych preferencji nabywców lub stwarzając nowe potrzeby i rynki. Z uwagi na znaczne koszty wprowadzenia nowego produktu na rynek przedsiębiorcy nie mogli pozwolić sobie na produkcję i wprowadzenie produktu na rynek bez wcześniejszej analizy rynku, zarówno pod względem konkurencji, jak i preferencji nabywców. Istotę orientacji marketingowej stanowi odpowiedni wybór, zdobycie lub stworzenie, a następnie utrzymanie rynku zbytu, który zapewniłby przedsiębiorstwu źródło przychodów odpowiednie do jego potrzeb i aspiracji rozwojowych.

Realizacja powyższych założeń wiązała się z nagłym i dużym zapotrzebowaniem na wyniki badań rynkowych, które stanowiły główne źródło informacji o rynku, oraz opracowaniem i koordynacją odpowiednich narzędzi, za pośrednictwem których przedsiębiorstwo mogło oddziaływać na wyselekcjonowane rynki nabywców. Jedną z zasad postępowania $\mathrm{w}$ tej dziedzinie jest oddziaływanie na dany rynek nie poszczególnymi instrumentami, lecz odpowiednio ukształtowaną ich kompozycją, zwaną marketing-mix (Altkorn 1997). Zasada ta polega na skoordynowaniu stosownych narzędzi tak, by wywołać zjawisko synergii, którego przejawem jest wzajemne działanie różnych czynników powodujące, że ich łączny efekt jest większy od sumy efektów ich działania osobnego. Największą popularność wśród rozmaitych prób przedstawienia struktury marketing-mixu zyskała Koncepcja Four Ps: product, price, place, promotion, zwana inaczej zasadą 4P, która w sposób znaczący wpłynęła na rozwój teorii marketingu. Elementy marketing-mixu oraz narzędzia oddziaływania na rynek przedstawia ryc. 1 .

Za pomocą tych narzędzi przedsiębiorcy skutecznie oddziaływali na docelowe rynki. Jednakże zaczęto dostrzegać, że aby przedsiębiorstwo osiagało lepsze wyniki, działania zawarte $\mathrm{w}$ koncepcji $4 \mathrm{P}$ powinny zostać poprzedzone strategicznym myśleniem STP segmentacją, wyborem rynku docelowego i pozycjonowaniem. Specjaliści od marketingu doszli do wniosku, że przedsiębiorstwo może działać na czterech różnych poziomach rynkowych. Wyodrębniono następujące poziomy: rynek masowy, segment rynku, nisza rynkowa oraz klient indywidualny (Kotler 2004). Rozwój marketingu jak i zmiany strukturalne w gospodarce krajów rozwiniętych przyczyniły się w latach 80 . XX w. do rozszerzenia procesów globalizacji. Zmiany w strukturze przemysłowej poszczególnych krajów pozwoliły na szybki rozwój korporacji ponadnarodowych. Dzięki dużej wielkości produkcji, zróżnicowaniu asortymentu oraz nieograniczonemu zasięgowi dystrybucji korporacje osiagały bardzo wysokie zyski. Rozwojowi podlegały nie tylko duże korporacje przemysłowe, których przedmiotem produkcji były produkty petrochemiczne i motoryzacyjne. Swoją działalność międzynarodową rozwinęły również przedsiębiorstwa z sektora elektronicznego, 
spożywczego, kosmetycznego i chemicznego. Ważnym czynnikiem dla rozwoju globalizacji było odejście od gospodarki centralnie sterowanej w krajach Europy Wschodniej. Dalszy rozwój systemów komunikacji i transportu, a także eliminacja czynników blokujących swobodny przepływ towarów i usług oraz ludności skutkował coraz silniejszym zacieśnianiem się stosunków międzynarodowych.

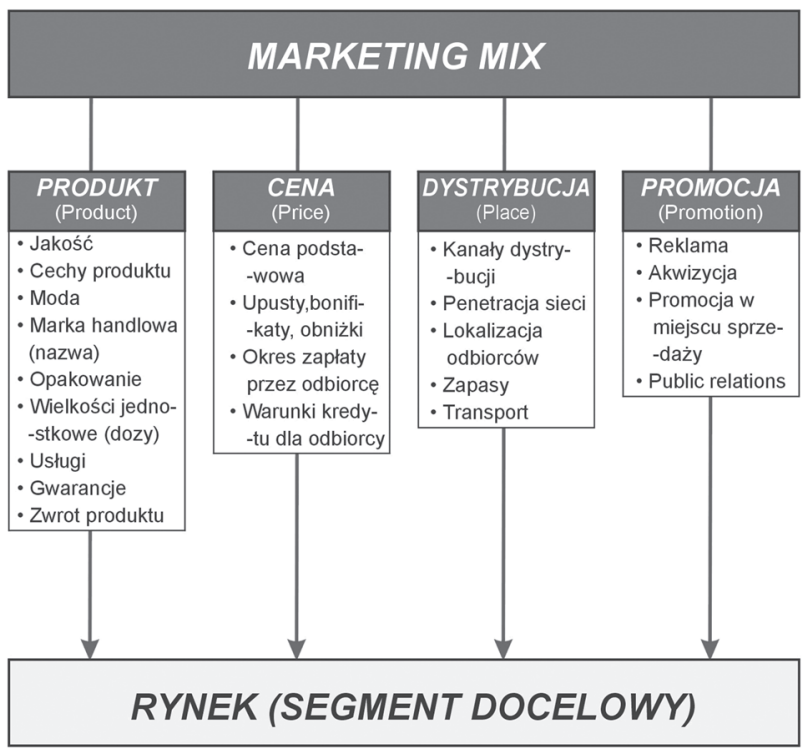

Rys. 1. Marketing-mix, jego elementy oraz narzędzia

Źródło: Wiśniewski A., 1994, Marketing I - Istota marketingu, Wyd. WSiP, Warszawa

W ostatnim dziesięcioleciu XX w. tendencje globalizacyjne znacząco się nasiliły, m.in. z powodu ponadnarodowej ekspansji banków. Liberalizacja polityki gospodarczej pozwoliła na wzrost liczby inwestycji ponadnarodowych. Z punktu widzenia dużych ponadnarodowych korporacji kraje postkomunistyczne stanowiły idealny, chłonny rynek zbytu. Od połowy lat 90. nastąpiło znaczne przyspieszenie procesu globalizacji. Głównym czynnikiem akceleracyjnym był rozwój Internetu oraz liberalizacja gospodarki w krajach postkomunistycznych. Internet stworzył wiele możliwości dla rozwoju biznesu, jak i narzędzi oddziaływania na rynek, ułatwił jego segmentację, a przede wszystkim pozwolił na szybkie dotarcie do wybranego segmentu, indywidualnego klienta lub znalezienia konkretnej niszy. Obecnie większość ponadnarodowych korporacji zmieniło swoją orientację marketingową na orientację marketingu strategicznego.

\section{Podsumowanie}

Globalizacja to historyczny proces liberalizacji i integracji rynków poszczególnych krajów w jeden ponadnarodowy rynek światowy. Nie można jednoznacznie stwierdzić, czy postępująca globalizacja była powodem ewolucji teorii marketingu. Proces globalizacji niewąt- 
pliwie przyczynił się do zmian w marketingowej orientacji przedsiębiorstw przemysłowych, ale nie był jedynym ich powodem. Ciagle zmieniające się warunki otoczenia, w którym funkcjonowały przedsiębiorstwa, niejako wymuszały zmiany w strategii marketingowej. Jednakże historyczne spojrzenie na problematykę globalizacji oraz analiza rozwoju teorii marketingu daje przesłanki do stwierdzenia, że oba te procesy oddziaływały na siebie, wzajemnie stymulując rozwój. Panujące stosunki społeczne, zmiany w regulacjach prawnych, poziom dostępnej techniki i technologii, wirtualny wymiar działalności, globalny zakres działalności gospodarczej i jej ograniczenia są czynnikami, które w istotny sposób wpływają na funkcjonowanie i rozwój przedsiębiorstw w warunkach globalnej gospodarki. Aby przedsiębiorstwo mogło skutecznie konkurować na rynku globalnym, powinno skutecznie reagować na zmiany w jego otoczeniu. Przez otoczenie rozumie się zbiór składników, takich jak pieniądze, materiały, ludzie, energia, informacje, których nie zalicza się do składników samej organizacji, ale ich bezpośrednie oddziaływanie lub zmiana właściwości może spowodować zmianę stanu samej organizacji (Pomykalski 2001). Nowoczesne przedsiębiorstwo powinno reagować na zmiany w swym otoczeniu, skutecznie wprowadzając innowacje, co pozwoli mu na osiągnięcie wielu znaczących efektów, które często przesądzają o istnieniu organizacji. Przedsiębiorstwa te poprzez innowacje polepszają i unowocześniają procesy wytwórcze, podnoszą produktywność, wydajność, a także jakość pracy. W ten sposób przedsiębiorstwo lepiej przystosowuje się do otoczenia, podnosi jakość swoich wyrobów, zwiększa ogólną sprawność i efektywność działania poprzez usprawnianie organizacji i metod pracy.

Przedsiębiorstwo ponadnarodowe staje się bardziej konkurencyjne na rynku globalnym wtedy, gdy tworzy i absorbuje nowe produkty i usługi oraz posiada zdolność ciagłego adaptowania się do zmian zachodzących w otoczeniu. Priorytetem w strategii zarządzania przedsiębiorstw ponadnarodowych powinno być umiejętne wykorzystanie narzędzi marketingowych, a przede wszystkim wdrażanie innowacji technicznych i organizacyjnych. Wzmocnienie pozycji konkurencyjnej i wzrost poziomu nowoczesności przedsiębiorstw ponadnarodowych jest możliwy dzięki strategii, w której innowacje stanowią punkt wyjścia dla pozostałych działań rynkowych. Przy wykorzystaniu tej strategii podstawowym celem przedsiębiorstwa powinno być generowanie i tworzenie innowacji w konfrontacji z wnikliwym rozpoznaniem potrzeb klienta.

\section{Literatura}

http://www.gazetabankowa.pl/pl/dokumenty/Historia1920_1929

http://www.shell.com/home/content/aboutshell-en/who_we_are/our_history/early_20th_century/early_20th_century_history_shell_22112006.html

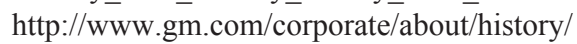

Szpak J., 2003, Historia gospodarcza powszechna, PWE Warszawa

$\mathrm{http}: / / \mathrm{www} . \mathrm{klm} . \mathrm{com} /$ travel/corporate_en/facts_figures/history/index.htm

Niestrój R., 1997, Istota i znaczenie marketingu, [w:] Podstawy marketingu, Altkorn J., red., Instytut Marketingu, Kraków www.stud.umk.pl/ kcz/polska_1918_39.htm\#1.3

Kotler Ph., 2004, Philip Kotler odpowiada na pytania na temat marketingu, REBIS, Poznań

http://pl.wikipedia.org/wiki/OEEC, 1

http://pl.wikipedia.org/wiki/GATT, 2

Jasiński A., 1992, Przedsiębiorstwo innowacyjne na rynku, KiW, Warszawa

Pomykalski A., 2001, Zarzadzanie innowacjami, PWN S.A., Warszawa 


\section{Changes in marketing orientation of industrial enterprises in the age of progressive globalization}

Globalization is not a new phenomenon. This process has been initiated by great geographic discoveries. One can say, that the first age of globalization has been started in the $19^{\text {th }}$ century. Continuous reducing of duty caused England to become the trade - open country. It allowed to accelerate the develpment of international business. In the end of the $19^{\text {th }}$ century, innovations were a significant factor for development of globalization. They enabled a boost of efficiency of enterpreneurship through organizing mass production, reducing elementary cost and reducing price of final products. Technical progress in transport was also a significant factor for development of globalization. Along with technical progress, enterprises were forced to change their market orientation. Development of telecommunication contributed to propagation of information and it allowed enterprises to react much more quickly to changes in their environment. Presently, globalization has adopted a different form. First of all, it proceseeds faster and it has the greatest territorial coverage. There is no doubt that modern enterprises face the great challenge of being more competing on the homogeneous international market. Marketing is a package of market management instruments and one of the basic manager orientation. Efficiency of the enterprise activity on the market is mainly dependent on the selection of proper marketing instruments. The main questions are: How to be competitive on the international market in the age of globalization? Has globalization played a big role in forming the marketing theory? 